\title{
PENGARUH PEMUPUKAN DAN KEDALAMAN GAMBUT PADA PRODUKSI INOKULUM MIKORIZA ARBUSKULA DALAM PENANGKARAN DENGAN INANG Sorghum bicolor (L.) Moench
}

(The Effect of Fertilizing and Peat Depth on the Production of Arbuscular Micoriza Inoculum in Captivity with Hosts of Sorghum bicolor (L.) Moench)

\section{Uray Nurtati, Hanna Artuti Ekamawanti, Wiwik Ekyastuti}

Fakultas Kehutanan Universitas Tanjungpura Pontianak. Jl. Daya Nasional Pontianak 78124

Email: uraynurtati@gmail.com

\begin{abstract}
The research was to obtain information about the combination of fertilizers in the production of arbuscular mycorrhizal inoculums of various depths. This research is using an experimental method. The research uses divided plot design (RPT) with a basic RAK pattern. The treatment factor consists of the main plot (peat depth $0-50 \mathrm{~cm}$ and $50-100 \mathrm{~cm}$ ) and subplot is a combination of fertilizer $(P 1=$ without fertilizing; $P 2=N P K+$ rubberwood vinegar; $P 3=$ $N P K+$ peat vinegar; $P 4=N P K+$ fern-root vinegar). Spore breeding process is \pm 3 months. Hosts use sorghum with sterile sand media. The observation variable consisted of the percentage of root infections and the number of spores. Data analysis using ANOVA. Identification of spores based on morphology and Melzer reaction. The results showed that fertilization factors affected the number of spores. The number of spores without fertilization was higher, namely 1642,500 spores compared to combination fertilizers (NPK+fern-root vinegar was 707,667 spores; NPK+rubberwood vinegar was 606,833 spores; NPK+peat vinegar was 206,667 spores). The rate of $0-50 \mathrm{~cm}$ colonization without fertilization, NPK+peat vinegar, NPK+rubberwood vinegar is included in the high category. Then in the treatment at $50-100 \mathrm{~cm}$ without fertilizing, NPK+peat vinegar, NPK+fern-root vinegar infection rates are also high. The type of spore found is Glomus sp.1; Glomus sp.2; Glomus sp.3; Glomus sp.4. The results of the number of spores and the percentage of root infections showed that organic vinegar was known to not stimulate FMA sporulation, but organic vinegar did not inhibit FMA colonization.
\end{abstract}

Keyword: Mycorrhizal, organic vinegar, peat depth, sorghum

\section{PENDAHULUAN}

Fungi mikoriza arbuskula (FMA) merupakan salah satu mikroorganisme yang dimanfaatkan sebagai agens hayati (biofertilizer). Pemanfaatan FMA dapat meningkatkan zona penyerapan dan ketersediaan hara serta resistensi terhadap cekaman air dan serangan hama penyakit (Setiadi 1999). Pengembangan dan pemanfaatan FMA menjadi salah satu alternatif dan solusi dalam mengatasi permasalahan konservasi terutama membantu pertumbuhan tanaman pada lahan-lahan kritis. Salah satu upaya yang dilakukan dengan menyediakan isolat-isolat FMA yang unggul, terutama dari jenis-jenis setempat. Tahap awal yang dilakukan dengan pembuatan kultur penangkaran. Pembuatan kultur penangkaran dilakukan dengan cara mencampur tanah dari lapangan sebagai inokulum 
dengan media tumbuh steril serta tanaman inang yang sesuai. Media tumbuh yang digunakan dapat berupa tanah, bahan mineral (pasir, zeolit dan sebagainya), bahan organik (kompos atau gambut) atau campuran ketiga dari bahan tersebut (Feldmann et al. 2009; Ijdo et al. 2011; Siddiqui dan Kataoka 2011). Selain media tumbuh, penentuan jenis tanaman inang juga harus diperhatikan. Menurut Nusantara et al. (2012) salah satu tanaman yang biasa digunakan yakni sorgum. Faktor lain yang dapat menentukan keberhasilan penangkaran adalah jumlah pemupukan dalam satuan pot kultur. Unsur hara yang mempengaruhi secara langsung maupun tidak langsung dalam pemupukan adalah unsur hara fosfor (P). Alternatif lain untuk memenuhi kebutuhan unsur hara dengan mengkombinasikan pupuk NPK dengan cuka organik. Hal ini dilakukan mengingat penggunaan pupuk kimia dalam kapasitas banyak akan mengganggu ekosistem di sekitarnya. Salah satu produk dari cuka organik yang umum dikenal masyarakat adalah cuka kayu. Cuka kayu memiliki banyak manfaat antara lain sebagai pestisida, penambah kesuburan dan perbaikan tanah (Payamara 2011). Menurut Rustamaji (Komunikasi pribadi 2018), cuka gambut dan cuka akar pakis juga diasumsikan memiliki kandungan yang sama dengan cuka kayu. Berdasarkan kelebihan dari cuka organik dapat dijadikan potensi untuk stimulan dalam produksi inokulum mikoriza arbuskula. Potensi ini perlu dilakukan pengujian untuk pengembangan dalam pemanfaatan cuka organik.

Tujuan penelitian untuk mendapatkan informasi tentang kombinasi pupuk dalam produksi inokulum mikoriza arbuskula dari berbagai kedalaman. Manfaat penelitian ini untuk pengembangan ilmu dan perkembangan teknologi (IPTEK), khususnya pada bidang bioteknologi hutan tentang alternatif dari penggunaan cuka organik untuk produksi inokulum mikoriza arbuskula.

\section{METODOLOGI}

Penelitian ini dilaksanakan di rumah kasa untuk proses penangkaran (trapping) dan di Laboratorium Silvikultur Fakultas Kehutanan UNTAN untuk proses pengamatan spora FMA dan pengamatan infeksi akar. Waktu penelitian \pm 6 bulan mulai dari persiapan bahan sampai proses pengamatan. Alat yang digunakan antara lain pot kultur, timbangan analitik, pinset spora, cawan Petri, tissue, gelas ukur, gelas piala, kertas label, objek glass, cover slip, mikroskop, 1 set saringan tanah, termometer tanah, termometer udara dan tally sheet. Bahan yang digunakan antara lain aquades, $\mathrm{NaOCl} 5,25 \%$, semai sorgum, pasir steril, pupuk NPK, cuka organik, sampel tanah gambut, larutan $\mathrm{KOH} 10 \%$, larutan staining (cuka makan komersial 5\% + tinta Quink hitam atau biru), larutan destaining $(500 \mathrm{~mL}$ gliserol $+450 \mathrm{~mL}$ $\mathrm{H}_{2} \mathrm{O}+50 \mathrm{~mL}$ cuka komersial 5\%) dan sampel akar tanaman penangkaran.

\section{Pelaksanaan Penelitian}




\section{Pengambilan sampel tanah gambut}

Sampel tanah gambut diambil \pm $200 \mathrm{gr} / \mathrm{sampel}$. Sampel tanah tersebut diambil pada 3 jalur dengan jarak $20 \mathrm{~m}$, $50 \mathrm{~m}$ dan $80 \mathrm{~m}$ dari tepi parit dan dilakukan pengambilan sampel tanah gambut pada kedalaman 0-50 cm dan 50-100 cm. Total sampel yang diambil sebanyak 18 sampel tanah. Masingmasing sampel tanah gambut dikompositkan sesuai jarak dan kedalaman sehingga didapatkan 6 sampel tanah.

2. Penyemaian benih sorgum

Benih disterilkan menggunakan $\mathrm{NaOCl} 5,25 \%$ selama \pm 5 detik kemudian dilakukan perendaman selama \pm 15 menit. Benih direndam kembali dengan air dingin. Setelah itu, benih dikeringkan kemudian ditaburkan pada bak plastik yang telah berisi pasir steril. Benih ditutup kembali dengan pasir steril. Bak plastik diletakkan pada rak kultur dan diberikan penerangan cahaya. Penyiraman benih dilakukan setiap pagi dan sore hari.

\section{Penangkaran spora FMA}

Masing-masing pot kultur diisi media tanam dan inokulum FMA. Pasir steril diletakkan pada bagian bawah sebanyak $1 / 4$ volume pot kemudian inokulum pada bagian tengah sebanyak $1 / 2$ volume pot, lalu pada bagian atas dilapisi kembali dengan pasir steril sebanyak $1 / 4$ volume pot. 3 bibit tanaman inang ditanam pada setiap pot kultur yang telah diisi media tanam dan inokulum FMA. Pot diletakkan pada bak plastik yang berisikan air dan diletakkan dalam rak kultur yang cukup cahaya selama \pm 1 minggu. Selama berada di rak kultur, tanaman hanya disiram dengan air (tanpa dilakukan pemberian pupuk). Setelah satu minggu kemudian tanaman dipindah ke rumah kasa.

\section{Pemberian cuka organik}

Pemberian cuka organik dilakukan pada pagi hari pukul 06.00 08.00 WIB dan sore hari pada pukul 16.00 - 18.00 WIB. Pemberian cuka organik dilakukan setiap dua kali dalam seminggu yaitu setiap hari Senin dan Kamis. Dosis pupuk komersil NPK (255-20) pada 1 g dilarutkan dalam 1 liter air sedangkan untuk pengenceran cuka organik $4 \mathrm{~mL}$ dalam 1 liter air. Banyaknya takaran pada satu pot kultur adalah $10 \mathrm{~mL}$ NPK $+10 \mathrm{~mL}$ cuka organik (kombinasi) yang telah dilakukan pengenceran.

\section{Pemeliharaan}

Pemeliharaan dilakukan dengan penyiraman air. Penyiraman air dilakukan pada pagi dan sore setiap hari kecuali hari Senin dan Kamis, karena setiap hari Senin dan Kamis akan dilakukan pemberian kombinasi pupuk NPK + cuka organik. Selain itu, pemeliharaan lain yang dilakukan dengan membersihkan daun-daun yang menguning pada setiap pot kultur. Pemeliharaan pada penangkaran spora FMA dilakukan selama \pm 3 bulan. Setelah itu akan dilanjutkan dengan proses pencekaman (stressing) selama \pm 2 minggu yaitu tanpa penyiraman air dan pupuk untuk merangsang sporulasi FMA.

\section{Pemanenan}




\section{Pemanenan dilakukan setelah proses pencekaman (stressing) selesai.} Daun dan tanah pada tanaman tersebut dipisahkan dengan menggunting pada bagian pangkal batang tanaman $\pm 1 \mathrm{~cm}$ menggunakan gunting yang tajam. Tanah yang berada pada setiap pot kultur dikeluarkan perlahan-lahan agar tanah tidak tumpah. Tanah kemudian dipindahkan kedalam kantong plastik yang sudah diberi label keterangan.

\section{Pengamatan infeksi akar}

Semua akar dicuci sampai bersih. Akar direndam dalam larutan $\mathrm{KOH}$ $10 \%$ selama 12-24 jam dengan tujuan untuk memutihkan akar tanaman tersebut. Kemudian akar dicuci dengan air yang mengalir sampai akar bersih. Akar diwarnai dengan merendamnya dalam larutan staining selama 24-72 jam. Setelah itu, akar direndam kembali dalam larutan destaining untuk menghilangkan kelebihan larutan pewarna pada akar. Akar yang telah diwarnai kemudian dipotong dengan ukuran $1 \mathrm{~cm}$ kemudian diambil secara acak sebanyak 10 potong dan meletakkannya berjajar pada gelas objek. Setiap 5 potong akar ditutup dengan sebuah cover slip. Potongan akar diamati menggunakan mikroskop.

\section{Isolasi spora FMA}

Sampel tanah hasil penangkaran dimasukkan kedalam gelas piala dan ditambahkan 1 L air. Sampel tanah diaduk hingga homogen dan dibiarkan beberapa menit agar partikel yang besar mengendap, kemudian dituang ke 1 set saringan dengan mesh $0,21 \mathrm{~mm}, 125$ $\mu \mathrm{m}, 63 \mu \mathrm{m}$ dan $45 \mu \mathrm{m}$. Endapan dibilas pada air yang mengalir. Endapan yang ada pada saringan $63 \mu \mathrm{m}$ dan $45 \mu \mathrm{m}$, dipindahkan ke dalam wadah. Air tanah yang bercampur dengan spora diambil sedikit demi sedikit ke cawan Petri yang telah diberi grid untuk kemudian dihitung.

9. Pembuatan preparat dan karakterisasi spora FMA

Spora diambil menggunakan pinset spora dan diambil sebanyak 2 spora pada masing-masing jenis. Spora diletakkan pada gelas objek yang telah diberi PVLG (Polyvynil alcohol lacto gliserol) pada bagian sebelah kanan, sedangkan pada bagian sebelah kirinya diberi PVLG + larutan Melzer. Selanjutnya spora ditutup menggunakan cover slip. Bagian tepi pada bagian cover slip dioles dengan cutex bening. Spora hasil isolasi kemudian diamati menggunakan mikroskop. Morfologi yang diamati berdasarkan bentuk spora, warna spora, tekstur dinding spora dan bentuk tangkai hifa yang melekat pada dinding spora kemudian diidentifikasi berdasarkan INVAM (2018).

\section{Rancangan Percobaan}

Penelitian ini menggunakan metode eksperimen dengan rancangan petak terbagi (RPT) pola dasar RAK. Faktor perlakuan terdiri dari petak utama yang merupakan sampel tanah gambut berdasarkan kedalaman 0-50 $\mathrm{cm}$ dan 50-100 cm dan anak petak yakni pemberian pupuk kombinasi antara pupuk NPK dengan jenis cuka organik yang berbeda-beda. Pemberian kombinasi pupuk NPK dan cuka organik terdiri dari P1 (tanpa 
pemupukan/kontrol), P2 (NPK + cuka kayu karet), P3 (NPK + cuka gambut) dan P4 (NPK + cuka akar pakis). Pengelompokan didasarkan pada pengambilan tanah gambut dari tepi parit yaitu $20 \mathrm{~m}, 50 \mathrm{~m}$, dan $80 \mathrm{~m}$.

\section{Pengumpulan Data}

Data yang dikumpulkan terdiri dari dua, antara lain data pokok dan data penunjang. Data pokok diperoleh pada saat pengamatan di laboratorium meliputi persentase akar yang terinfeksi FMA dan jumlah spora FMA per $135 \mathrm{~g}$ media. Data penunjang diperoleh pada saat pengambilan sampel tanah gambut dilapangan meliputi data $\mathrm{pH}$ tanah, suhu tanah, suhu udara dan kelembapan udara.

\section{HASIL DAN PEMBAHASAN}

\section{Produksi Inokulum Mikoriza}

\section{Arbuskula}

Hasil perhitungan dari analisis keragaman jumlah spora FMA /135 g media setelah ditransformasi $\sqrt{\mathrm{x}}$ dapat dilihat pada Tabel 1 .

Tabel 1. Analisis keragaman RPT (Analysis of RPT diversity)

\begin{tabular}{ccccccc}
\hline $\begin{array}{c}\text { Sumber } \\
\text { Keragaman }\end{array}$ & $\begin{array}{c}\text { Derajat } \\
\text { Bebas } \\
(\mathbf{d b})\end{array}$ & $\begin{array}{c}\text { Jumlah } \\
\text { Kuadrat } \\
(\mathbf{J K})\end{array}$ & $\begin{array}{c}\text { Kuadrat } \\
\text { Tengah } \\
(\mathbf{K T})\end{array}$ & F-hitung & \multicolumn{2}{c}{ F tabel } \\
\hline Kedalaman (D) & 1 & 593,225 & 593,225 & 7,682 tn & 18,51 & 98,5 \\
Pemupukan (P) & 3 & 2000,359 & 666,786 & $10,088 * *$ & 3,49 & 5,95 \\
Interaksi (DP) & 3 & 42,995 & 14,332 & 0,217 tn & 3,49 & 5,95 \\
\hline
\end{tabular}

Keterangan: $\mathrm{tn}=$ tidak berpengaruh nyata $* *$ = berpengaruh sangat nyata

Berdasarkan hasil analisis keragaman pada Tabel 1 menunjukkan bahwa faktor pemberian pupuk berpengaruh sangat nyata pada jumlah spora FMA setelah inokulasi selama 14 minggu, sedangkan kedalaman gambut dan interaksi kedalaman gambut dan interaksi keduanya tidak berpengaruh nyata. Selanjutnya untuk mengetahui faktor pemberian pupuk yang menunjukkan perbedaan rerata jumlah spora FMA, maka dilakukanlah uji beda nyata terkecil (BNT). Hasil uji BNT respons jumlah spora terhadap pemberian pupuk dalam penangkaran dapat dilihat pada Tabel 2.

Tabel 2. Uji BNT rerata jumlah spora per $135 \mathrm{~g}$ media (The LSD test averages the number of spores oer 135 g media)

\begin{tabular}{cc}
\hline Perlakuan & Rerata \\
\hline Tanpa pemupukan (Kontrol) & $1642,500 \mathrm{a}$ \\
NPK + cuka kayu karet & $606,833 \mathrm{~b}$ \\
NPK + cuka gambut & $206,667 \mathrm{c}$ \\
NPK + cuka akar pakis & $707,667 \mathrm{~b}$
\end{tabular}

Keterangan: - Rerata yang diikuti huruf sama, tidak berbeda nyata dengan uji BNT pada taraf $\alpha=0,05$

- Rerata yang diikuti huruf yang beda, berbeda nyata dengan uji BNT pada taraf $\alpha=0,05$

Berdasarkan hasil uji BNT tersebut dapat diketahui bahwa dari keempat perlakukan dalam penangkaran spora FMA, rerata jumlah spora yang 
dihasilkan dari perlakuan tanpa pemupukan (kontrol) lebih tinggi yaitu 1642,500 spora /135 g media. Perlakuan NPK + cuka akar pakis dan NPK + cuka kayu karet juga menghasilkan rerata jumlah spora lebih banyak dari perlakuan NPK + cuka gambut, sedangkan rerata jumlah spora FMA paling rendah pada perlakuan pemberian pupuk kombinasi NPK + cuka gambut yaitu 206,667 spora /135 g media. Hasil penelitian ini menunjukkan bahwa tanpa pemupukan (kontrol) yang menggunakan tanaman inang Sorghum bicolor (L.) Moench dapat menghasilkan spora paling banyak dibandingkan dengan pemberian pupuk NPK + cuka organik (kombinasi). Peningkatan jumlah spora tersebut dapat disebabkan miskinnya unsur hara P yang tersedia dalam tanah. Hasil analisis cuka organik diketahui bahwa unsur hara $\mathrm{P}$ pada masingmasing cuka organik tersebut memiliki unsur hara $\mathrm{P}$ yang tinggi, sedangkan pada pupuk NPK kandungan unsur hara $\mathrm{P}$ nya rendah. Kadar konsentrasi unsur hara $\mathrm{P}$ pada cuka akar pakis yakni $6 \%$, Cuka gambut 8\%, sedangkan pada pupuk NPK kandungan unsur hara $\mathrm{P}$ lebih rendah dari cuka akar pakis dan cuka gambut hanya 5\%, akan tetapi perbedaan hasil jumlah spora pada masing-masing keempat perlakuan tersebut dapat juga disebabkan oleh faktor internal maupun eksternal lainnya yang tidak dapat dikendalikan oleh manusia.

Inokulum mikoriza arbuskula tidak hanya berupa spora FMA, namun dapat juga berupa akar yang terinfeksi mikoriza. Persentase kolonisasi akar ditentukan dari adanya infeksi akar oleh spora FMA dengan ditemukannya struktur seperti vesikel, arbuskula dan hifa eksternal pada jaringan korteks. Akar yang terinfeksi FMA dapat dilihat pada Gambar 1.

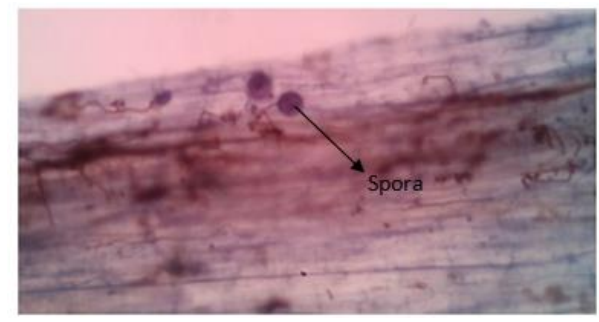

Gambar 1. Infeksi FMA pada akar tanaman Sorghum bicolor (L.) Moench (FMA infection in the roots of Sorghum bicolor (L.) Moench)

Rerata tingkat infeksi akar pada masing-masing perlakuan didapatkan hasil yang bervariasi mulai dari klasifikasi kelas 3 (sedang) hingga kelas
4 (tinggi). Data nilai rerata persentase akar yang terinfeksi FMA dapat dilihat pada Tabel 3. 
Tabel 3. Nilai rerata persentase akar yang terinfeksi FMA serta klasifikasi infeksinya (The average value of the percentage of roots infected with FMA and the classification of the infections)

\begin{tabular}{cccc}
\hline $\begin{array}{c}\text { Kedalaman } \\
\text { Gambut } \\
(\mathbf{C m})\end{array}$ & $\begin{array}{c}\text { Pemupukan } \\
\text { Kombinasi } \\
(\mathbf{m L})\end{array}$ & $\begin{array}{c}\text { Rerata Persentase } \\
\text { Infeksi Akar }(\boldsymbol{\%})\end{array}$ & Klasifikasi Infeksi \\
\hline \multirow{3}{*}{$0-50 \mathrm{~cm}$} & Tanpa pemupukan & $60 \%$ & Kelas 4 (tinggi) \\
& NPK + cuka kayu karet & $56,6 \%$ & Kelas 4 (tinggi) \\
& NPK + cuka gambut & $63,3 \%$ & Kelas 4 (tinggi) \\
& NPK + cuka akar pakis & $46,6 \%$ & Kelas 3 (sedang) \\
\hline \multirow{3}{*}{$50-100 \mathrm{~cm}$} & Tanpa pemupukan & $63,3 \%$ & Kelas 4 (tinggi) \\
& NPK + cuka kayu karet & $46,6 \%$ & Kelas 3 (sedang) \\
& NPK + cuka gambut & $53,3 \%$ & Kelas 4 (tinggi) \\
& NPK + cuka akar pakis & $60 \%$ & Kelas 4 (tinggi) \\
\hline
\end{tabular}

Tabel 3 menunjukkan bahwa rerata persentase infeksi akar dari kedalaman gambut $0-50 \mathrm{~cm}$ pada perlakuan tanpa pemupukan $(60 \%)$, NPK + cuka kayu karet $(56,6 \%)$, NPK + cuka gambut $(63,3 \%)$ tergolong dalam kategori tinggi. Kedalaman gambut 50-100 pada perlakuan tanpa pemupukan $(63,3 \%)$, NPK + cuka gambut $(53,3 \%)$ dan NPK + cuka akar pakis (60\%) juga termasuk dalam kategori tinggi yakni diatas 51\%$75 \%$ yang tergolong dalam kelas 4 . Kemudian rerata persentase infeksi akar yang termasuk dalam kategori sedang berkisar 26\%-50\% terdapat pada kedalaman 0-50 dengan perlakuan NPK + cuka akar pakis $(46,6 \%)$ dan kedalaman 50-100 cm pada perlakuan NPK + cuka kayu karet $(46,6 \%)$. Nilai rerata infeksi akar tersebut menunjukkan hasil infeksi akar yang berbeda dengan jumlah spora FMA dalam tanah. Hal ini menunjukkan bahwa tidak ada keterkaitan antara perlakuan yang memiliki jumlah spora rendah akan memiliki persentase infeksi akar yang rendah pula, begitu pula sebaliknya. Perlakuan pada NPK + cuka gambut memiliki rerata jumlah spora yang paling sedikit akan tetapi dalam hal infeksi akar memiliki persentase yang tinggi. Hal ini membuktikan bahwa tidak ada korelasi antara jumlah spora FMA dengan persentase infeksi akar. Sporulasi yang rendah juga tidak menjadi penghambat dalam perbanyakan inokulum mikoriza arbuskula.

Pemanfaatan kolonisasi akar yang tinggi pada perlakuan tanpa pemupukan (kontrol) dan pemberian kombinasi pupuk juga bisa dijadikan sumber inokulum. Hal ini dikarenakan akar yang telah terinfeksi oleh FMA mengandung miselium internal dan eksternal serta spora. Kolonisasi akar yang terinfeksi FMA akan lebih cepat terjadi dalam 1-2 hari setelah inokulasi dilakukan dibandingkan dengan spora FMA yang berada dalam tanah membutuhkan waktu untuk berkecambah sehingga membutuhkan waktu lebih lama lagi (Gunawan 1993). Hasil dari rerata jumlah spora dan persentase akar yang terinfeksi FMA ini menunjukkan bahwa cuka organik belum dapat menstimulasi sporulasi FMA di dalam tanah, akan tetapi cuka organik juga tidak menghambat kolonisasi FMA di dalam akar. Hal ini 
dikarenakan produksi spora dan infeksi akar juga dapat dipengaruhi oleh faktor genotif tanaman dan faktor lingkungan (Lukitaningdyah 2013).

Pemilihan tanaman inang yang cocok dan mempunyai sistem perakaran yang baik buat mikoriza dapat menjadi penyebab tingginya intensitas infeksi akar. Nusantara et al. (2012) mengungkapkan bahwa salah satu tanaman yang umum digunakan sebagai inang dalam perbanyakan FMA adalah Sorgum (Sorghum bicolor (L.) Moench). Menurut Deptan (1990), tanaman sorgum mampu tumbuh didaerah beriklim tropis dan subtropis sehingga memiliki toleransi terhadap kekeringan maupun kondisi basah. Tumbuh baik pada lahan yang kurang subur serta dapat tumbuh hampir disetiap jenis tanah. Tanaman sorgum juga dapat membentuk akar-akar sekunder dua kali lebih banyak, berakar dalam dan fibrous sehingga lebih efektif dalam menyerap hara dan air. Hal yang serupa juga diungkapkan oleh Abdullah et al. (2005) bahwa karakteristik sorgum yang mempunyai akar-akar sekunder menyebabkan FMA akan lebih mudah menginfeksi akar, sehingga intensitas infeksi akar menjadi tinggi.

Selain tanaman inang, lingkungan juga berpengaruh terhadap kolonisasi akar dan produksi spora FMA. Tanah gambut yang digunakan memiliki $\mathrm{pH}$ tanah yang rendah atau asam. Hasil analisis kimia tanah menunjukkan bahwa $\mathrm{pH}$ tanah gambut dari kedalaman $0-50 \mathrm{~cm}$ dan $50-$ $100 \mathrm{~cm}$ memiliki pH berkisar antara 3,3 3,7 dengan ketersediaan unsur hara yang rendah, akan tetapi $\mathrm{pH}$ tanah yang demikian tidak mengganggu pertumbuhan dari mikoriza tersebut. Hal ini dikarenakan FMA memiliki sifat acidophilic yaitu senang kondisi asam (Setiadi 1994) sehingga memungkinkan bagi FMA untuk tetap hidup. Ketersediaan unsur hara pada tanah gambut Desa Kuala Dua, Rasau Jaya yang rendah juga dapat juga menjadikan salah satu pendorong FMA untuk melakukan simbiosis dengan tanaman. Selain $\mathrm{pH}$ tanah, suhu juga mempengaruhi pertumbuhan dan pembentukan koloni spora mikoriza. Data hasil pengukuran dilapangan didapatkan rerata suhu tanah $29,3^{\circ} \mathrm{C}$, suhu udara $28,1^{\circ} \mathrm{C}$ serta kelembapan udara 56,4 \%. Menurut Sastrahidayat (2011), Suhu udara yang tinggi menghasilkan akar yang terinfeksi FMA menjadi tinggi serta dapat meningkatkan sporulasi FMA. Hal serupa juga diungkapkan oleh Hetrick (1984) bahwa suhu udara yang terbaik untuk perkembangan arbuskular adalah $30^{\circ} \mathrm{C}$, untuk kolonisasi miselium pada permukaan akar antara $28^{\circ} \mathrm{C}-34^{\circ} \mathrm{C}$ serta untuk sporulasi dan perkembangan vesikel pada suhu $35^{\circ} \mathrm{C}$. Berdasarkan hasil pengukuran dilapangan sporulasi dan infeksi akar masih bisa terjadi karena masih termasuk dalam suhu terbaik untuk perkembangan mikoriza tersebut.

Hasil karakterisasi jenis spora per 135 g media ditemukan 1 (satu) genus yaitu genus Glomus. Jumlah spora FMA pada tiap jenis per $135 \mathrm{~g}$ media (setelah 14 minggu diinokulasi) dapat dilihat pada Tabel 4 berikut ini. 
Tabel 4. Jumlah jenis spora FMA per 135 g media (The total of FMA spores per 135 g media)

\begin{tabular}{ccccccc}
\hline \multirow{2}{*}{$\begin{array}{c}\text { Kedalaman } \\
\text { Gambut }\end{array}$} & Tipe Spora & $\begin{array}{c}\text { Tanpa } \\
\text { pemupukan }\end{array}$ & $\begin{array}{c}\text { NPK+cuka } \\
\text { kayu karet }\end{array}$ & $\begin{array}{c}\text { NPK+cuka } \\
\text { gambut }\end{array}$ & $\begin{array}{c}\text { NPK+cuka } \\
\text { akar pakis }\end{array}$ & Total \\
\hline \multirow{5}{*}{$0-50 \mathrm{~cm}$} & Glomus sp.1 & 4130 & 1174 & 520 & 1490 & 7314 \\
& Glomus sp.2 & 218 & 145 & 62 & 73 & 498 \\
& Glomus sp.3 & 118 & 99 & 64 & 97 & 378 \\
& Glomus sp.4 & 1958 & 1145 & 355 & 836 & 4294 \\
\hline \multirow{5}{*}{$50-100 \mathrm{~cm}$} & Total & 6424 & 2563 & 1001 & 2496 & 12484 \\
\hline & Glomus sp.1 & 2379 & 534 & 141 & 952 & 4006 \\
& Glomus sp.2 & 141 & 76 & 11 & 81 & 309 \\
& Glomus sp.3 & 95 & 23 & 15 & 83 & 216 \\
& Glomus sp.4 & 816 & 445 & 72 & 634 & 1967 \\
\hline & Total & 3431 & 1078 & 239 & 1750 & 6498 \\
\hline
\end{tabular}

Tabel 4 menunjukkan bahwa jenis spora yang ditemukan terdiri dari 4 jenis antara lain Glomus sp.1, Glomus sp.2, Glomus sp.3 dan Glomus sp.4. Spora yang lebih banyak ditemukan terdapat pada Glomus sp.1. dan jenis spora yang paling sedikit ditemukan Glomus sp.3. Spora FMA dari keempat jenis tersebut hampir ditemukan pada setiap perlakuan dari kedalaman gambut 0-50 cm sampai kedalaman 50-100 cm. Hasil karakterisasi spora FMA menunjukkan bahwa FMA pada tanah gambut Desa
Kuala Dua, Rasau Jaya lebih didominasi oleh genus Glomus. Hal ini dikarenakan Glomus mempunyai daya adaptasi yang lebih tinggi terhadap lingkungan tanah masam. Hal serupa juga diungkapkan oleh Huda (2016), bahwa genus Glomus memiliki tingkat penyebaran dan adaptasi yang tinggi terhadap lingkungan yang ekstrim sekalipun. Karakterisasi jenis spora FMA pada keempat jenis tersebut dapat di lihat pada Tabel 5.

Tabel 5. Karakteristik tipe spora FMA (Characteristic of FMA type spores)

\begin{tabular}{|c|c|c|c|}
\hline No. & Tipe Spora & Gambar Spora & Karakteristik Spora \\
\hline 1 & $\begin{array}{c}\text { Glomus } \\
\text { sp.1 }\end{array}$ & & $\begin{array}{l}\text { Bentuk spora elips, warna spora merah } \\
\text { kehitaman, terdiri dari } 3 \text { lapisan dinding } \\
\text { spora, tekstur permukaan spora kasar, } \\
\text { tangkai hifa lurus serta tidak bereaksi } \\
\text { dengan Melzer. }\end{array}$ \\
\hline 2 & $\begin{array}{c}\text { Glomus } \\
\text { sp. } 2\end{array}$ & & $\begin{array}{l}\text { Bentuk spora bulat, warna spora merah } \\
\text { pudar, terdiri dari } 2 \text { lapisan dinding spora, } \\
\text { tekstur permukaan spora halus serta tidak } \\
\text { bereaksi dengan Melzer. }\end{array}$ \\
\hline
\end{tabular}




\section{3 \\ Glomus sp.3 \\ 4 \\ Glomus sp.4
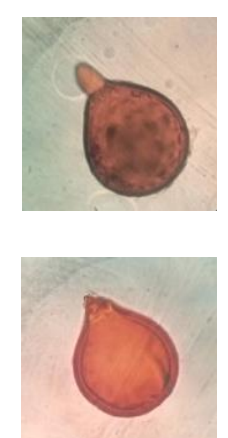 \\ Potensi Cuka Organik untuk Stimulasi dalam Produksi Inokulum Mikoriza Arbuskula sebagai Agen Hayati}

Bentuk spora bulat, warna spora merah kecoklatan, terdiri dari 2 lapisan dinding spora, tekstur permukaan spora halus, tangkai hifa lurus serta tidak bereaksi dengan Melzer.

Bentuk spora bulat, warna spora merah bata, terdiri dari 3 lapisan dinding spora, tekstur permukaan spora halus dan tidak bereaksi dengan Melzer.

Produksi inokulum mikoriza arbuskula merupakan kegiatan untuk menghasilkan produk mikoriza arbuskula berupa spora, akar yang bermikoriza dan hifa interseluler atau hifa intraseluler. Hasil dari penelitian cuka gambut memiliki potensi dalam kolonisasi akar untuk produksi inokulum mikoriza arbuskula karena tingkat infeksi FMA tinggi pada kedua kedalaman gambut yakni kedalaman gambut 0-50 cm dan 50-100 $\mathrm{cm}$. Cuka akar pakis dan cuka kayu karet juga memiliki potensi untuk produksi inokulum mikoriza berupa infeksi akar bermikoriza, yakni cuka akar pakis pada kedalaman gambut 50-100 cm sedangkan cuka kayu karet pada kedalaman gambut 0-50 cm. Kolonisasi yang tinggi pada akar ini dapat dimanfaatkan sebagai sumber inokulum yang infektif dan efektif. Hal ini dikarenakan kolonisasi akar yang terinfeksi FMA lebih cepat terjadi dalam 1-2 hari setelah inokulasi dibandingkan dengan spora (Gunawan 1993). Selain itu, cuka organik juga termasuk pupuk yang ramah lingkungan daripada pupuk NPK dan cuka organik memiliki banyak manfaat. Menurut Payamara (2011), cuka kayu memiliki beberapa manfaat

diantaranya pengendalian hama,

meningkatkan kesuburan tanah, zat akselerasi pertumbuhan tanaman, pengatur pertumbuhan tanaman atau penghambat pertumbuhan. Rustamaji (Komunikasi pribadi 2018) juga mengungkapkan bahwa cuka akar pakis dan cuka gambut memiliki manfaat kurang lebih sama seperti cuka kayu. Hasil dari inokulum mikoriza arbuskula berupa infeksi akar bermikoriza ini belum diketahui keefektifitasannya sebagai stimulan, sehingga perlu dilakukan penelitian lebih lanjut.

Penelitian ini merupakan penelitian dasar. Tujuan jangka panjang dari penelitian ini adalah untuk produksi agens hayati mikoriza arbuskula yang potensial. Peran cuka organik dalam produksi agens hayati mikoriza arbuskula perlu digali lebih dalam melalui penelitian-penelitian tentang dosis cuka organik terbaik, media tumbuh dan inang yang sesuai dalam produksi inokulum ini. Harapannya setelah ditemukan dosis cuka organik terbaik, media tumbuh dan inang yang sesuai untuk produksi agens hayati dapat diaplikasikan pada tanaman-tanaman kehutanan di lahan tanah gambut yang terdegradasi ini. Kegiatan restorasi lahan gambut dengan memanfaatkan agens hayati mikoriza arbuskula yang potensial 
sebagai upaya untuk mengatasi permasalahan konservasi yang terjadi.

\section{Kesimpulan}

Faktor pemberian pupuk berpengaruh terhadap jumlah spora FMA. Jumlah spora pada perlakuan tanpa pemupukan (kontrol) lebih tinggi daripada pemberian pupuk kombinasi. Jumlah spora pada perlakuan NPK + cuka akar pakis dan NPK + cuka kayu karet lebih tinggi dibandingkan dengan perlakuan NPK + cuka gambut. Jumlah spora FMA paling rendah terdapat pada perlakuan pemberian pupuk kombinasi NPK + cuka gambut. Pengamatan infeksi akar menunjukkan bahwa perlakuan tanpa pemupukan (kontrol) dan perlakuan NPK + cuka gambut memiliki tingkat infeksi FMA yang tinggi pada kedua kedalaman gambut yakni $0-50 \mathrm{~cm}$ dan $50-100 \mathrm{~cm}$. NPK + cuka akar pakis pada kedalaman 50-100 cm dan NPK + cuka kayu karet pada kedalaman 0-50 cm juga memiliki tingkat infeksi FMA yang tinggi. Karakterisasi jenis spora FMA ditemukan 1 (satu) genus yaitu Glomus yang terdiri dari 4 jenis spora berbeda-beda antara lain Glomus sp.1, Glomus sp.2, Glomus sp.3 dan Glomus sp.4. Hasil rerata jumlah spora dan persentase akar yang terinfeksi oleh FMA menunjukkan bahwa cuka organik diketahui belum dapat menstimulasi sporulasi FMA di dalam tanah, akan tetapi cuka organik juga tidak menghambat proses kolonisasi FMA di dalam akar.

\section{Saran}

Produksi inokulum mikoriza arbuskula untuk tujuan menghasilkan spora FMA tertinggi dapat menggunakan perlakuan tanpa pemupukan (kontrol) sedangkan kolonisasi akar yang tinggi untuk dijadikan sumber inokulum dapat menggunakan perlakuan NPK + cuka gambut. Perlu dilakukannya penelitian lebih lanjut terkait dengan dosis cuka organik, media tumbuh dan inang yang sesuai dalam menghasilkan produksi inokulum mikoriza arbuskula terbaik.

\section{UCAPAN TERIMA KASIH}

Terima kasih kepada SEAMEO BIOTROP melalui Dr. Ir. Hanna Artuti Ekamawanti, M.Si (sebagai Ketua Peneliti) yang telah membantu dana penelitian ini dari DIPA Biotrop 2017 yang berjudul "Pengembangan Sistem Paludikultur untuk Lahan Gambut Terdegradasi: Karakteristik Lahan Gambut dan Teknik Propagasi Tumbuhan Indigenos".

\section{DAFTAR PUSTAKA}

Abdullah S, Musa Y, Feranita. 2005. Perbanyakan Cendawan Mikoriza Arbuskular (CMA) pada Berbagai Varietas Jagung (Zea mays L.) dan Pemanfaatannya pada Dua Varietas Tebu (Saccharum officinarum L.). Jurnal Sains dan Teknologi 5: 1220.

Cruz C, Green JJ, Watson CA, Wilson F, Loucao MAM. 2004. Functional Aspect of Root Architecture and Mycorrhizal Inoculation with Respect to Nutrient Uptake Capacity. Mycorrhiza 14: 177-184.

Departemen Pertanian. 1990. Teknologi Budidaya Sorgum. Jayapura: Balai Informasi Pertanian Provinsi Irian Jaya.

Feldmann F, Hutter I, Schneider C. 2009. Best Production Practice of Arbuscular Mycorrhizal Inoculum. Soil Biol 18: 319-335. 
Gunawan AW. 1993. Mikoriza Arbuskula. Pusat Antar Universitas. Bogor: Institut Pertanian Bogor.

Huda N. 2016. Asosiasi Fungi Mikoriza Arbuskula (FMA) pada Tanaman Gaharu Aquilaria spp. Di Desa Laman Satong Kabupaten Ketapang. Jurnal Hutan Lestari 4: 72-81.

Komarayati S, Pari G. 2014. Pengaruh Arang dan Cuka Kayu terhadap Peningkatan Pertumbuhan dan Simpanan Karbon. Jurnal Penelitian Hasil Hutan 32: 313-328.

Nusantara AD, Bertham YH, Mansur I. 2012. Bekerja dengan Fungi Mikoriza Arbuskula. Bogor: Seameo Biotrop.

Payamara J. 2011. Usage of Wood Vinegar as New Organic Substance. International Journal of Chemtech Reseacrh 3: 1658-1662.

Rasyid A, Lapanjang MI, Barus HN. 2016. Kepadatan dan Keragaman Fungi Mikoriza Arbuskula pada Pertanaman Jagung (Zea Mays L.). Jurnal Agroland 23: 141-148.

Rustamaji. 2018. Komunikasi Pribadi Tentang Cuka Kayu Karet, Cuka Gambut dan Cuka Akar Pakis.

Sastrahidayat IR. 2011. Rekayasa Pupuk Hayati Mikoriza dalam Meningkatkan Produksi Pertanian. Malang: Universitas Brawijaya Press.

Setiadi Y. 1999. Gambut Tantangan dan Peluang. Jakarta: Departemen Pekerjaan Umum. 